\title{
Gaining Historical Perspective on Political Fact-Checking: The Experience of the United States
}

\author{
James W. Cortada \\ Charles Babbage Institute, \\ University of Minnesota Twin Cities, USA \\ jcortada@umn.edu \\ William Aspray \\ Department of Information Science, \\ Charles Babbage Institute, USA \\ william.aspray@icloud.com
}

\begin{abstract}
Objective. This paper provides an historical perspective on the wide use of fake facts in modern American society, and the efforts of librarians, journalists, and others to scrutinize public discourse as well as printed and online materials in order to differentiate fake facts from truth.

Results. The paper identifies six historical factors that influenced both the belief in truth as a value and the ability to carry out these evaluations: (1) the rise in various kinds of literacy and numeracy; (2) expansion of data-driven government; (3) the rise of scientific and social science research; (4) an expanding progressive sentiment to address social problems; (5) the transformation of the media to become fact-driven; and (6) the creation of a data and computing infrastructure robust enough to handle real-world problems. All six factors were in effect, at least in an incipient form, by the end of the nineteenth century.
\end{abstract}

\section{INTRODUCTION}

Librarians, journalists, scientists, and some other professionals have demonstrated a will to truth as Nietzsche (1873 \& 1886) phrased it, in contrast to a number of current politicians who demonstrate a will to power. ${ }^{1}$ For these latter individuals, truth is a secondary consideration, subservient to achieving their goals; truth is valuable only if it is a means to their ends. ${ }^{2}$

\footnotetext{
${ }^{1}$ For a more extended discussion of these concepts, see the section entitled "Facts and Lies as a Socially Constructed Reality" in Chapter 1 of Fake News Nation by Cortada and Aspray (2019), In addition to the scholars described in that section (Alexandre Koyre, Emile Durkheim, Michel Foucault, Thomas Kuhn, Margaret Egan, Jesse Shera, Bruno Latour, Steve Woolgar, Steve Fuller, Leslie March, Christian Onof, Alvin Goldman, Thomas Blanchard, and of course Friedrich Nietzsche), one might want to consider Objectivity by Daston and Galison (2010); The Social Construction of What? (Hacking, 1999); and A History of the Modern Fact (Poovey, 1998).

${ }^{2}$ Donald Trump and other politicians are not the only ones who rely on fake facts or question the value of truth. In our contemporary world, for example, there are those who deny the scientific evidence of climate change, the coverage by the Fox network of news, the reality of the Sandy Hook massacre, and
} 
This paper introduces the main historical factors that shaped both our ability to discern truth from falsehoods in our increasingly complex world, and our valuing truth as an important goal. To determine both truth and value, it is most conspicuous preceding the political fact-checking operations that are so prevalent today. Here, we examine the exogenous factors over the past two centuries that led scrutiny to be valued in American society and that enabled individuals in their personal and work lives to be able to practise scrutiny in such varied situations as political fact-checking, rumor and legend debunking, and evaluation of the authenticity of cultural artifacts. The United States was selected for examination since worldwide interest in its current political affairs is intense. Fact-checking took place because many residents embraced the cultural values one calls science.in American public life today in political fact-checking. But to live effectively in today's complex, modern world, an individual must also have a well-honed sense of scrutiny in order to differentiate truth from falsehood, identify whether some representation is authentic, or understand the cultural meaning of an event or message. An important task for the modern librarians, of value to researchers and observers, is helping people to evaluate the truth or falsity of material found in online and printed sources.

Scrutiny is "the careful and detailed examination of something in order to get information about it." "3 This essay argues that this quest has a history that long preceded the political fact-checking operations that are so prevalent today. Here, we examine the exogenous factors over the past two centuries that led scrutiny to be valued in American society and that enabled individuals in their personal and work lives to be able to practise scrutiny in such varied situations as political fact-checking, rumor and legend debunking, and evaluation of the authenticity of cultural artifacts. Fact-checking took place because many residents embraced the cultural values one calls science.

How scrutiny is carried out speaks to the public's aspiration to know truth - a hallmark of scholarly aspirations, too. It is the mechanism used to arrive at truth. It is based epistemologically on a common belief system and culture popularly known as the scientific method. However, what is often most contested is how we know that something is truthful, not simply that truth is of value. We have identified themes that have been applied to arrive at truth. Of course, knowing if one has arrived at truth is not confirmed by the existence of the six cross-cutting themes identified below, but they are the mechanisms used to get there and are so widely deployed that we assume they have given people confidence that these get them to truth or close enough to reinforce beliefs, which gives one confidence to make a decision or take an action.

Six cross-cutting themes in American history contributed to the rise of scrutiny, including debunking and fact-checking. These themes also created a fertile environment for a national epistemology based on empirical truth, extending into North America a long and well-established tradition from Europe dating back to the seventeenth century. As students of that tradition pointed out, experimentation and observation were core practices (Shapin \& Schaffer, 1986). We can see direct lines of such behavior already evident in the behavior of educated Virginians observing and experimenting with crops on their plantations - notably

the benefits of vaccination. In Cortada and Aspray's (2019) Fake News Nation, eight historical examples of lies and misrepresentation in American public life are given in detail.

${ }^{3}$ Cambridge dictionary, https://dictionary.cambridge.org/us/dictionary/english/scrutiny. The concept of scrutiny is an important one, deserving of further elaboration. We will not do so here, but instead point the reader to Chapter 1 ("The Concept of Scrutiny") in Aspray and Cortada's (2019) From Urban Legends to Political Fact-Checking. 
James Madison and Thomas Jefferson, both of whom displayed some of the behaviors described here. We limit the discussion to identifying and describing these six cross-currents: (1) the rise in various kinds of literacy and numeracy; (2) expansion of data-driven government; (3) the rise of scientific and social science research; (4) an expanding progressive sentiment to address social problems; (5) the transformation of the media to become fact-driven; and (6) the creation of a data and computing infrastructure robust enough to handle real-world problems. Table 1 presents an overview of these six exogenous forces.

Throughout the course of American history, there have been people who have consciously set out to find methods for searching out the truth. Thomas Jefferson is a good example. He read the latest studies about scientific farming from Europe. He experimented with crops that would fare well in his soil and weather conditions, importing and even smuggling in seeds to use in experiments on his farm. He introduced crop rotation in order to avoid wearing out the nutrients in his fields. He invented a new plow that would reach deeper into the soil so as to uncover better nutrients and reduce topsoil loss. He collected weather data. He encouraged the formation of agricultural societies to disseminate best farming practices (Jewett, n.d.). He was an early adopter of fact-driven farming. However, by the second half of the nineteenth century, many farmers in America collected data on weather and crop production.

Americans first became seriously interested in scrutiny in the second half of the nineteenth century, when data began to be produced in greater quantities, government became increasingly data-driven, big business came of age, and the newspapers began to hire professionals to check the correctness of stories they were printing. ${ }^{4}$ With a concatenation of these multiple themes at work, America becomes a place in which scrutiny is more important and fact-checking begins to be commonplace and professionalized. ${ }^{5}$ This pattern has continued throughout the twentieth and twenty-first centuries, despite the strong presence of forces that value truth only as a means to an end.

\section{THE RISE OF LITERACIES}

Fact-handling in the United States has largely been a combination of documenting information in writing and then using collections of facts drawn primarily from publications. Fact-checking was typically a response to printed content. The information infrastructure in the United States was robust from earliest times. Key components of that infrastructure included high rates of literacy based upon widely diffused education of children and, later, adults; availability of large numbers of books and academic journals that were both affordable and peer reviewed; a growing network of public and school libraries; and massive diffusion of newspapers and, later, of magazines, radio, and television; and finally, organizations that produced prodigious amounts of information, such as US government agencies and higher educational institutions. The nation's ability to move this information was also a factor. The Post Office was the earliest and most obvious facilitator for moving information, especially newspapers; but before the Civil War, the telegraph, roads, railroads, and canals also became convenient transporters for facts. In the second half of the nineteenth century, these modes of

\footnotetext{
${ }^{4}$ On the overall history of information in America, see Fake News Nation by Cortada and Aspray (2019); and All the Facts: A History of Information in the United States Since the 1870s by Cortada (2016).

${ }^{5}$ One might argue that these developments are in part driven by the acceptance in America of $18^{\text {th }}$ century Enlightenment ideas. See Enlightenment Now: The Case for Reason, Science, Humanism, and Progress by Pinker (2018).
} 
transporting information expanded in quantity and the telephone came into use. By the time of the First World War, radio was available.

Over time, new forms of literacy became essential in order to acquire, use, judge, and store information. These included a growing need for mathematical and statistical literacy, and later the ability to use computing. Less well recognized was the need, since the early 1800 s, for a mechanical literacy that facilitated the creation, use, and maintenance of tools and machines. Each of these types of literacy plays a role in the history of scrutiny.

As early as the seventeenth century, literacy made it possible to transmit facts to children and adults in printed form rather than only through conversation. By the late eighteenth century, nearly 90 percent of men in New England could sign their name, just slightly more than the percentage of women (Gordon \& Gordon, 2003). ${ }^{6}$ A better measure of literacy involves the schooling of children, which was carried out at home as well as in churches and schools in the $18^{\text {th }}$ and much of the $19^{\text {th }}$ centuries, before public school systems became almost universal across the United States. In New England, where most early American citizens lived, almost every town had a school by 1800. Children received several years of education, meaning they learned to read in addition to acquiring knowledge of mathematics, history, religion, and (for boys) surveying (Wagoner. 2013; Reese, 2005). By the end of the 1800 s, over 80 percent of the people raised in the United States could read and write more than their signature. In the next century, as shown in Table 2, demographic exceeded 90 percent.

Driving the high rates of literacy at the beginning of the $20^{\text {th }}$ century were the high rates of school attendance. Prior to the Civil War, White children typically received fewer than five years of formal education, while Black and Indian children typically received no formal education. After the Civil War, enrollment rates increased across the nation. For Blacks, enrollment rose from approximately 10 percent in 1870 to 34 percent in 1880 (National Assessment of Adult Literacy, n.d). By 1900, when a national movement to increase education was underway, overall enrollment rates for ages 5 to 19 had reached 51 percent and grew to 75 percent by 1940. By the early 1970s, both White and Black student enrollments had reached approximately 90 percentage - a level that remained constant until the end of the century (National Assessment of Adult Literacy, n.d.). School enrollment of children ages 7 to 13 have remained steady at 99 percent since the late 1940s, while the percentage for older children has hovered between 83 and 90 percent since the Second World War (National Assessment of Adult Literacy, n.d.). Only half the adult population had completed eight years of education by 1940; but by the late 1940s and 1950s, half of the adult population had completed high school. The percentages did not change until the 1960s, when over 70 percent of all men and women had a high school diploma. At this same time, college education was increasing: the overall adult population who had attended college rose to 10 percent in the 1960s, and to 25 percent by the end of the century (National Assessment of Adult Literacy, n.d.). What these statistics tell us is not only that people learned to read, but they also had acquired a growing body of knowledge about mathematics, history, civics, information query, and (unevenly) critical thinking and writing skills. Thus, many had learned the rudiments for separating false from accurate information.

\footnotetext{
${ }^{6}$ On the rationale for counting signatures, see The History and Power of Writing by Martin (1994).
} 
Table 1. Six exogenous forces contributing to scrutiny in America

\begin{tabular}{|c|c|c|c|}
\hline Force & Features and trends & Examples & When initiated \\
\hline \multirow[t]{3}{*}{ Rise in literacy } & \multirow{2}{*}{$\begin{array}{l}\text { Spread of schooling among } \\
\text { children increased critical } \\
\text { thinking }\end{array}$} & $\begin{array}{l}\text { Public schooling made } \\
\text { mandatory }\end{array}$ & $1900-1940$ \\
\hline & & $\begin{array}{l}\text { Rising high school graduation } \\
\text { rates }\end{array}$ & $1925-1965$ \\
\hline & $\begin{array}{l}\text { Increased number of libraries, } \\
\text { publications expanded knowledge }\end{array}$ & $\begin{array}{l}\text { Number of books published } \\
\text { increased }\end{array}$ & 1880-Present \\
\hline \multirow{5}{*}{$\begin{array}{l}\text { Big } \\
\text { government \& } \\
\text { data driven } \\
\text { governance }\end{array}$} & Military scientific research & Louis \& Clark expedition & 1804-1806 \\
\hline & $\begin{array}{l}\text { Creation of civilian data } \\
\text { collection agencies }\end{array}$ & Weather data & $1850 \mathrm{~s}-1870 \mathrm{~s}$ \\
\hline & \multirow[t]{2}{*}{ Support of higher education } & Census bureau & $\begin{array}{l}1790, \text { continuous } \\
1900\end{array}$ \\
\hline & & New Deal agencies & $1930 \mathrm{~s}$ \\
\hline & Use of data processing tools & National Science Foundation & $1950 \mathrm{~s}-1960 \mathrm{~s}$ \\
\hline \multirow{4}{*}{$\begin{array}{l}\text { Rise of } \\
\text { scientific \& } \\
\text { social science } \\
\text { research }\end{array}$} & $\begin{array}{l}\text { Granted universities with R\&D } \\
\text { missions }\end{array}$ & $\begin{array}{l}\text { State university agricultural } \\
\text { research and farmer education }\end{array}$ & $1860 \mathrm{~s}-1880 \mathrm{~s}$ \\
\hline & $\begin{array}{l}\text { Expanded libraries for fact } \\
\text { finding }\end{array}$ & Library of Congress & 1800 \\
\hline & Scientific research projects & Census, weather databases & \multirow{2}{*}{$\begin{array}{l}\text { 1790s, 1850s } \\
1880 \text { s onward, } \\
\text { massive surge } \\
\text { post World War II }\end{array}$} \\
\hline & $\begin{array}{l}\text { Formation of professional } \\
\text { associations }\end{array}$ & $\begin{array}{l}\text { Medical knowledge displaced } \\
\text { quackery }\end{array}$ & \\
\hline \multirow{3}{*}{$\begin{array}{l}\text { Expanding } \\
\text { progressive } \\
\text { sentiment }\end{array}$} & $\begin{array}{l}\text { Reformed corrupt business } \\
\text { and labor abuses }\end{array}$ & $\begin{array}{l}\text { Anti-monopoly, labor and } \\
\text { child labor laws passed }\end{array}$ & $1890 \mathrm{~s}-1920 \mathrm{~s}$ \\
\hline & $\begin{array}{l}\text { Expanded investigatory reporting } \\
\text { based on facts }\end{array}$ & $\begin{array}{l}\text { Reporting on meat packing, } \\
\text { chemical and drug abuses }\end{array}$ & $1904-1920 \mathrm{~s}$ \\
\hline & Social reforms & $\begin{array}{l}\text { Food and drug administration } \\
\text { established }\end{array}$ & 1906 \\
\hline \multirow{4}{*}{$\begin{array}{l}\text { Transformed } \\
\text { media } \\
\text { industries and } \\
\text { professions }\end{array}$} & Professionalization of journalism & $\begin{array}{l}\text { Journalists established fact- } \\
\text { based practices }\end{array}$ & Post 1870s \\
\hline & $\begin{array}{l}\text { Academics embraced scientific } \\
\text { methods across all disciplines }\end{array}$ & & $\begin{array}{l}\text { Massively after } \\
1880\end{array}$ \\
\hline & $\begin{array}{l}\text { Balanced reporting regulations for } \\
\text { radio, TV }\end{array}$ & & $\begin{array}{l}\text { Radio 1920s, } \\
\text { TV 1950s }\end{array}$ \\
\hline & Blogging & & $2000 \mathrm{~s}$ \\
\hline \multirow{3}{*}{$\begin{array}{l}\text { Punch-card } \\
\text { tabulating data } \\
\text { \& computing } \\
\text { infrastructure }\end{array}$} & Massive data processing & Census, billing, accounting & $1890 \mathrm{~s}, 1950 \mathrm{~s}$ \\
\hline & Large computers & Customer databases & 1960 \\
\hline & $\begin{array}{l}\text { Communications between } \\
\text { computers \& Internet }\end{array}$ & Emails & $1970 \mathrm{~s}$ \\
\hline
\end{tabular}


Table 2. Percentage of residents 14 year's old and over who were literate, 1870-1979

\begin{tabular}{c|c|c|c}
\hline Year & Total & Total white & Total black \& other \\
\hline 1870 & 80 & 88 & 20 \\
\hline 1900 & 89 & 93 & 56 \\
\hline 1930 & 95 & 97 & 84 \\
\hline 1969 & 98 & 99 & 96 \\
\hline 1979 & 99 & 99 & 98 \\
\hline
\end{tabular}

Source: U.S. Department of Commerce, Bureau of the Census, Historical Statistics of the United States, Colonial Times to 1970 (Washington, DC.: US Government Printing Office, 1975), and Current Population Reports, Series P-23, Ancestry and Language in the United States, November 1979 (prepared September 1992).

Table 3. US doctorates conferred in the natural sciences and select other disciplines, 1920-1970, select years

\begin{tabular}{|c|c|c|c|c}
\hline Year & Natural Sciences* & Medical & Agriculture & Psychology \\
\hline 1920 & 220 & 50 & 17 & 35 \\
\hline 1930 & 783 & 154 & 61 & 101 \\
\hline 1940 & 1,260 & 307 & 94 & 129 \\
\hline 1950 & 2,686 & 420 & 252 & 360 \\
\hline 1960 & 3,504 & 755 & 414 & 772 \\
\hline 1970 & 10,481 & 2,233 & 918 & 1,888 \\
\hline
\end{tabular}

*Physics, astronomy, chemistry, earth science, mathematics, engineering, other biology Source: US Bureau of the Census, Historical Statistics of the United States: Colonial Times to 1970 (Washington, D.C.: US Government Printing Office, 1975): Part 1, p. 387.

Table 4. US doctorates conferred in social sciences, humanities, professional fields, education, 1920-1970, select years

\begin{tabular}{c|c|c|c|c|c}
\hline Year & Economics & $\begin{array}{c}\text { Social Sciences } \\
\text { (a) }\end{array}$ & $\begin{array}{c}\text { Humanities } \\
\text { (b) }\end{array}$ & Professional & Education \\
\hline 1920 & 22 & 30 & 119 & 31 & 48 \\
\hline 1930 & 107 & 104 & 415 & 96 & 268 \\
\hline 1940 & 125 & 179 & 628 & 94 & 470 \\
\hline 1950 & 243 & 373 & 934 & 219 & 1,032 \\
\hline 1960 & 352 & 544 & 1,454 & 382 & 1,549 \\
\hline 1970 & 853 & 1,822 & 4,060 & 1,203 & 5,859 \\
\hline
\end{tabular}

(a) Anthropology, sociology, political science, other social sciences.

(b) History, English, American literature, foreign languages and literature, other arts and humanities. Source: US Bureau of the Census, Historical Statistics of the United States: Colonial Times to 1970 (Washington, D.C.: US Government Printing Office, 1975): Part 1, p. 388. 
The ability to perform the four basic functions of arithmetic became a parallel form of literacy from colonial times. To conduct business, track inventory, pay accurately, make change, charge enough to make a profit, and even to count were all functions performed daily by children and adults. For over a dozen generations, children memorized the multiplication tables. From the seventeenth century on, school curricula included instructions on mathematical literacy. Various occupations were based on this body of knowledge, most notably bookkeeping and accounting. By the 1920s, high school students were routinely exposed to more advanced forms of mathematics, such as geometry and algebra, that were useful in various jobs and careers. In college, and occasionally in high school, they could learn trigonometry and calculus. ${ }^{7}$ These basic literacies were prerequisite to studying and pursuing a career in the natural sciences and engineering since before the First World War. ${ }^{8}$ Several spinoffs to mathematical literacy emerged. Surveying was an essential skill for a farmer or public official in order to define exact land boundaries of one's farm, township, or state (Linlater, 2002). ${ }^{9}$ George Washington made a living surveying before opting for a dual military and farming career. Surveying continued as a core literacy until late in the nineteenth century. Another literacy was the ability to read maps. Not until maps were digitized in the early 2000 s and route guidance was automated did that requirement decline. School children had been taught how to read maps since the 1600s. The military taught this skill to soldiers. Boy scouts were mandated to learn that skill since the founding of the organization in $1908 .{ }^{10}$ Even today, it is reckless to go hiking and camping in wilderness areas without the ability to read paper maps. ${ }^{11}$

Accounting has a long history, but with so many bookkeepers by the early nineteenth century, the best had learned how to read long columns of figures and intuitively understand them even before carrying out the calculation (Previts \& Merino, 1998; Johnson \& Kaplan, 1987). This task was so important that an entire industry developed in the second half of the nineteenth century to automate many of its functions - first known as the Office Appliance Industry, selling adding machines, calculators, and cash registers. It evolved into the Data Processing Industry by the 1910s, selling billing machines, tabulators, and eventually computers (Cortada, 1993). Within accountancy, the professional fake-fact finders were known as auditors, still a thriving group today; their sole purpose is to discover and correct inaccurate calculations and uncover financial fraud.

A third variant of mathematical literacy that remains more essential today than at any prior time in American history was the use of statistics. It has a rich history and as a form of literacy became a critical tool used in mathematics, natural science, engineering, and the social sciences (including sociology, demography, economics, education, and political

\footnotetext{
${ }^{7}$ This is a subject that requires more exploration by historians, but see National Council of Teachers of Mathematics (1970), Sinclair (2008) and Robert (2012).

The Teaching and History of Mathematics in The United States (Cajori, 1890) is still an essential study on the subject.

${ }^{9}$ Now automated through GPS and GIS systems on computers.

${ }^{10}$ See, for example, Surveying for Boy Scouts with Chapters on Map Reading, which was made available to boys in the United States; Map Reading and Land Navigation are still taught by US military, Headquarters Department of the Army.

${ }^{11}$ See as one of many hundreds of examples, one from the Great Smoky Mountains Trail Map and Guide: http://friendsofthesmokies.org/wp-content/uploads/2018/04/Trail-Map-GSMNP-06-2014.pdf
} 
science) by the late nineteenth century. ${ }^{12}$ By the early 1950s, it became increasingly difficult to graduate from a college or university without exposure to statistics. In the 1970s and 1980s, the use of statistics penetrated various sectors of American industry and by the 1990s had its own application and name, Total Quality Management (TQM), used to measure the performance and problems in industrial and business processes. Its leading advocate was $\mathrm{W}$. Edwards Deming, a low-level federal statistician in the 1930s who went on to become a worldwide icon of American managerial efficiencies in the 1950s (Aguayo, 1991; Gabor 1992).

Another offshoot of mathematical literacy was the ability to write software for computers, beginning in the 1940s but expanding dramatically in the late 1950s, using programming languages, such as FORTRAN, that used mathematical notations. Today, many people face the issue of being able to use applications on personal computers, tablets, and cell phones to perform routine tasks such as email, spreadsheets, word processing, and Web search and browsing (Hitlin, 2018). These computational skills are arguably now more important to the public than basic arithmetical skills, which have been automated by one's calculator, digital watch, and smart phone.

Another important form of literacy for early residents of North America was the ability to fix their equipment and tools and, by the dawn of the Second Industrial Revolution, to design, operate, and maintain machines, factory equipment, and vehicles. These skills were later employed by electricians, plumbers, mechanics, and computer repair people. These skills, which involved real-world applications of mathematical knowledge, were learned through apprenticeships and on-the-job experiences, not formal education. ${ }^{13}$ Between the $1790 \mathrm{~s}$ and the 1850s, this form of literacy became important and began to appear in publications that called for workers to understand characteristics of materials, draw objects in proportion, conduct calculations involving gears and other moving parts of machinery, read and produce technical documentation, and measure and use the four basic arithmetical functions with fractions (Stevens, 1995). Mechanical literacy filled the gap between what one was taught in school and what one needed in the workplace (Stevens,1995, pp. 105-108). The rapid growth of vocational schools in the twentieth century reflected the growing need for this kind of literacy.

These various forms of literacy teach us several lessons. Literacy was and continues to involve an evolving set of skills required to function in a society. As new technologies and jobs emerged, basic skills regarding how to handle the information changed, often expanding rather than displacing earlier forms of literacy. Reading and writing skills, for example, are as necessary today as they were two hundred years ago. With so much information today being created and disseminated through the Internet, a new form of digital literacy is emerging. That digital literacy includes a resurgence in the old eighteenth century Enlightenment idea of seeking out truth and hard data. ${ }^{14}$

\footnotetext{
${ }^{12}$ Stigler's (1986) The History of Statistics: The Measurement of Uncertainty before 1900-and his collection of essays (2002), Statistics on the Table: The History of Statistical Concepts and Methods. ${ }^{13}$ One major exception was high school "shop classes," taught since the First World War, where students learned to measure before cutting wood or metal, and in designing items to be made in class. ${ }^{14}$ While we are pointing in this essay to one specific, positive influence of the Enlightenment, this is not to say that there were not also negative influences. For a more complete account of the influence of the Enlightenment, see for example, Foucault (1984), White (1973) and Megill (1994).
} 


\section{BIG GOVERNMENT AND DATA-DRIVEN GOVERNANCE}

By the time the U.S. Government Printing Office was established in 1860, federal agencies and departments had been creating new knowledge for over a half century. The Army and Navy played a crucial role in recording geographic, cultural, and economic knowledge about the United States. These efforts shifted the nation's views of the country from rumor and unreliable older publications to nearly real-time facts gathered in a methodical, scientific way. Several examples illustrate this work. In 1804, President Jefferson funded a small, Army-led expedition to explore the territory the United States had acquired from France through the Louisiana Purchase the previous year. By its completion in 1806, the expedition had mapped vast sections of North America. This was part of a larger mapping exercise that occupied the Army for the next 75 years, which discovered new plants and animals, identified Indian tribes and their lands, and acquired an understanding of deserts, forested regions, and the weather, as well as providing basic geographic information about the continental United States.

The Army was given responsibility for installing a network of telegraph networks across the West. While conducted primarily for national security, it also facilitated commerce and population movement (Schwoch, 2018). Army personnel linked the telegraph across the Rockies, into the Southwest, along the Mexican border, and even through Alaska after its acquisition by the United States in 1867. Using this network of telegraph stations, the Army began to collect vast quantities of information about the movement of Indians and military actions; and just prior to the Civil War, it also began the methodical collection of weather data. This mission continued until the late nineteenth century, when that function was turned over to civilian government employees who were tagged with producing fact-based weather forecasts (Schwoch, 2018, pp. 85-92). It is a mission the US government still performs today (Lewis, 2018). The Navy conducted similar research and data gathering at sea (Hearn, 2002). ${ }^{15}$

By the 1870 s, these government employees produced information about the land, maps, and weather of greatly enhanced quality compared, for example, to the widely used Farmer's Almanac, published since 1792. The railroads and telegraph companies, and those dependent on their information, increasingly relied on government data. This data was more current; some was updated every week.

Beginning in 1790 and continuing to the present, every ten years the American government conducted a census of the nation. Each decade the US Congress determined what questions census takers were to explore. Over time, the number of questions extended far beyond determining how many people lived in the United States, marital status, number of residents in a home, and where they lived. By the beginning of the twentieth century, ad hoc census taking had been formalized with the establishment of the Bureau of the Census. Its permanent staff conducted numerous, detailed studies of the nation's population, economy, literacy, and social circumstances - all to enable fact-driven public policy and administration. During his time as Secretary of Commerce after the First World War, Herbert Hoover brought into his department scientific and statistical methods for measuring economic activity; and this new data informed the many new agencies created during the administration of President Franklin D. Roosevelt (1933-1945) (Duncan \& Shelton, 1978). Federal agencies expanded the nation's understanding of agricultural practices, poverty, national security, crime, and health in support of the New Deal programs of the 1930s (Duncan \& Shelton, 1978, pp. 195-214).

\footnotetext{
${ }^{15}$ See, for example, Tracks in the Sea: Matthew Fontaine Maury and the Mapping of the Oceans by Hearn (2002).
} 
By the end of the Second World War, citizens generally viewed the American government as an unbiased, massive producer of information that the nation could and did rely upon. Fact checking by government workers was about ensuring the accuracy of the data collected. This effort encouraged the use of data processing equipment - at first, tabulators and punch cards beginning with the 1890 census, and later computers (Cortada, 2008). ${ }^{16}$

After the Second World War, the federal government created new agencies that led to the creation and collection of data: the National Institutes of Health, which consolidated various medical research initiatives of the US government dating back to the 1870s and expanded in the years 1946 to 1949; the National Science Foundation, created in 1950, which funded roughly 85 percent of scientific research conducted in the United States during the second half of the twentieth century; and the Advanced Research Projects Agency, established in 1958 to address the need for scientific information for conducting the Cold War in support of the Department of Defense. All three institutions spent the majority of their efforts supporting the creation of new facts, as did other mission-oriented agencies of the federal government, including NASA (space and astronomy), the Department of Energy (nuclear energy and weapons), and the Department of Agriculture. Americans and their employers came to rely extensively on the massive production of federal data, which grew exponentially in quantity and quality in the twentieth century.

\section{The Rise of Natural and Social Science Research}

The rise of the scientific method began in the $16^{\text {th }}$ century and was characterized by a commitment to argument, experiment, and reason as the foundation for knowledge (Andersen \& Hepburn, 2015). ${ }^{17}$ The two main figures involved in creating the scientific method were Francis Bacon (Jardine \& Stewart, 2000; Gower, 1997) (1561-1626) and Isaac Newton (1642-1726). In the Novum Organon, Bacon described the method of induction for arguing carefully and systematically from a collection of data and observations to fundamental, general laws. Bacon's rules upended the basis of scientific knowledge in the philosophy of Aristotle or in religious or metaphysical thinking. As the philosopher William Whewell (1794-1866) argued in System of Logic, Bacon's method was too time consuming and cumbersome to actually be used by scientists. Nevertheless, it was seen as an ideal. In the $17^{\text {th }}$ century, for example, the research of Robert Boyle (1627-1691) in chemistry and of William Harvey (1578-1657) in anatomy and physiology were guided by Bacon's inductive methods. As time went on, induction was accepted as a critical element of the method of creating scientific knowledge. In his two major works, Opticks and Principia Mathematica, Newton developed his method of scientific deduction, arguing from general principles to specific instantiations of those principles, which could then be tested against observable reality. The success of Newton's method was recognized most clearly in his laws of gravitation. These dual methodological approaches of induction and deduction became an underpinning of the Enlightenment in the eighteenth century.

By the nineteenth century the scientific method had been shown to yield great understanding (solid factual information as well as a general and theoretical understanding) in many natural sciences - first in physics and astronomy, but later in chemistry, geology, and

\footnotetext{
${ }^{16}$ For an extended discussion, see The Digital Hand, vol. 3, How Computers Changed the Work of American Public Sector Industries by Cortada (2008).

${ }^{17}$ For a philosophically sensitive account of the scientific method and its historical development, see Scientific Method by Andersen \& Hepburn (2015).
} 
the biological sciences. As early as the seventeenth century, Thomas Hobbes (1588-1679) had tried in his major work, Leviathan, to consciously build a science of politics and government based on deductive analysis from axioms, explicitly following Newton's method. In the nineteenth century, Auguste Comte (1797-1857) and later Emile Durkheim (1858-1917) created sociology as a scientific discipline, following methodological approaches already developed in the natural sciences. Thus, in the nineteenth century, the study of human behavior, by then called the social sciences, came under the rule of the scientific method.

Closely associated with the rise of social science was the rise of statistics. The term was used in the eighteenth century to mean the systematic collection of data, which at that time tended to be either economic or demographic data. In the nineteenth century, mathematics was introduced into statistics, in particular the use of mathematical probability theory, and the concept of statistical inference was introduced. These methods of mathematical statistics were applied in the first half of the nineteenth century to crime, marriage, and suicide rates by Adolphe Quetelet (1796-1874) and later in the century by Francis Galton (1822-1911) to eugenics and psychometrics and by Karl Pearson (1857-1936) to evolutionary theory and biometrics. Thus, by the second half of the nineteenth century, there were well-established and well-accepted methods for gaining knowledge in both the natural and social sciences.

The scientific methods were brought into wider practice by being introduced into the university system, which expanded considerably in the United States during the second half of the nineteenth century, especially through the first and second Morrill Acts (1862 and 1890), which created land-grant colleges and universities across the nation - typically taking up practical subjects such as agriculture and engineering, to which they applied these scientific methods. In the United States alone, over 1,300 colleges and universities were supporting academic research during the second half of the twentieth century (Marcus, Geiger et al., 2015; Marcus, Bix et al. 2015). ${ }^{18}$ There were also full-time scientists and engineers working in the private sector, who increasingly applied scientific methods of research and data analysis across a growing range of subject areas.

With the development of large, science-based corporations beginning in the $1880 \mathrm{~s}$, companies conducted research that could be converted into products, and that called for them to establish research labs. The most famous were Thomas Edison's Menlo Park, which produced everything from the light bulb and citywide electrical services to movies and sound recording; and AT\&T's telephone laboratory, Bell Labs, which was at mid-twentieth century the single largest employer of science and engineering doctorates outside of higher education. For example, Bell Labs invented the transistor, the core innovation of the first computers. Dozens of private-sector laboratories existed by the start of the Second World War (Galambos, 2012; Cortada, 2019, pp. 112-113; Reich, 1985). Both the academic and industrybased scientists and engineers relied in part on the massive databases developed and nurtured by the US government. By the mid-twentieth century, one common type of research involved large, data-driven activities. Because private-sector research centers were more generously funded than most academic initiatives, the former could take on larger data-based projects,

\footnotetext{
${ }^{18}$ Service as Mandate: How American Land-Grant Universities Shaped the Modern World, 1920-2015 by Marcus, Geiger et al. (2015) and the companion volume, Science as Service: Establishing and Reformulating American Land-Grant Universities, 1865-1930
} 
such as interviewing tens of thousands of people instead of, say, the hundreds or a few thousand interviews a lone academic researcher could handle. ${ }^{19}$

The unrelenting expansion of new facts in kind and number since the seventeenth century challenged the notion of what constituted a fact, and how facts were received and used, giving them a plasticity that could be shaped to support one's world views, needs, or wants. ${ }^{20}$ The universities, government data collection agencies, and corporate R\&D centers were all involved in the creation of facts to shape human activities. The multiplication of data led to metaphors, for example, about printed information reaching from the Earth to the Moon, and to general problems related to both the quality and the overload of information. Meanwhile, the massive growth in the amount of information accelerated in the nineteenth century continued right through the following century. ${ }^{21}$ One useful and continuing source of all this new information was amateur science encouraged, for example, by the British government handing out prizes for solving thorny mathematical and navigational problems for several centuries. ${ }^{22}$

With so many participants today, even traditional natural ${ }^{23}$ and social science ${ }^{24}$ research is challenged, or at least not as confidently accepted, as in prior times. Today, scientists and experts no longer have a monopoly on the creation, expression, and dissemination of information. There are a number of science doubters, especially among certain groups with a political or religious view they wish to espouse. With the ability of individuals and organizations with specific political, social, or religious agendas to collect, sort, and distribute

${ }^{19}$ One of our authors (Cortada) worked at IBM's management research center, the Institute for Business Value, which had a staff of some 60 employees who routinely leveraged the entire company's sales force to interview thousands of executives around the world in 1- to 3-hour sessions, just to produce one or a few reports. Their behavior was similar to that of other business think tanks. ${ }^{20}$ Mathematics provides an interesting example here. Until the $19^{\text {th }}$ century, following the Ancient Greek lead, mathematics was thought to be a representation of the world (of physical space), so there was only one geometry: Euclidean geometry. But in the $19^{\text {th }}$ century, the conceptualization of mathematics changed. It was now about the logical conclusions of formal systems whose axioms humans chose. Thus, there was much greater freedom in what mathematicians studied, including numerous non-Euclidean geometries that were internally consistent but which contradicted the 2000year-old Euclidean geometry. See Mathematics: The Loss of Certainty by Kline (1982).

${ }^{21}$ See, for example, the case made by Weinberger (2011). On the other hand, hundreds of years earlier people also believed that there was too much to know. See Too Much to Know: Managing Scholarly Information before the Modern Age by Blair (2011).

${ }^{22}$ The most famous of which was the hunt for a formula to calculate longitude for sailing, by Sobel (1998).

${ }^{23}$ A related issue is the argument from the philosophers and the social scientists that science is socially constructed and does not present absolute truth about the physical world, which sets it apart from other kinds of knowledge. See, for example, An Introduction to Science and Technology Studies, $2^{\text {nd }}$ ed. by Sismondo (2009), Objectivity by Daston and Galison (2010), The Social Construction of What? by Hacking (1999). Scientists began to recognize that historians were not apologists for the scientific method but were instead questioning its absolute truth as early as the well-known article Should the History of Science Be X-Rated? by Brush (1974).

${ }^{24}$ Studies of how voters behaved in a particular election, based on going through all their ballots, are interesting, but will it inform political behavior today? The authors of such studies hope so, but many politicians and political scientists believe the data is too old and not relevant. A recent study that received considerable attention in Spain involved the last national elections in Spain before the start of the Spanish Civil War in 1936, elections that were considered corrupt, but never proven to be so until Tardio and Garcia (2017) did such a massive study. 
information through use of computers and the Internet, they can compete for everyone's attention. ${ }^{25}$ While this competition always existed, that competition for "mind-share" increase dramatically with the arrival of the Internet and self-publishing. ${ }^{26}$

As people acquired more information, what they did with it increased too. In both the natural and the social sciences, concerns surfaced. Psychologist Steven Pinker recently felt the need to defend reason, science, and humanism, but in the process argued that, "the standard explanation of the madness of crowds is ignorance: a mediocre education system that has left the populace scientifically illiterate, at the mercy of their cognitive biases, and thus defenseless against airhead celebrities, cable-news gladiators, and other corruptions from popular culture." (Pinker, 2018 p. 355) This Harvard professor felt under siege. But he and others have also seen the use of the scientific method, statistics, computers, and now the Internet to create more accurate information, often by the increased collaboration of investigators across multiple disciplines. This trend is reversing the older practice dating from the 1870s of specializing, now returning to the even earlier model of integration, or to use a modern expression, "interdisciplinarity". Pinker (2018) again pointed out: "One of the greatest potential contributions of modern science may be a deeper integration with its academic partner, the humanities." (p. 405).

The drive to data is becoming commonplace in some disciplines, such as in archeology, which has become a high-tech, computer-intensive discipline, as it has in the quantitativelydriven economic history and increasingly in sociology. Historians, long reluctant to change their methods, are engaging too, with old norms challenged, such as questioning the value of always studying the state; privileging elites, firms, and institutions; engaging in retrospective rationalizations; searching for the next paradigm; flirting with scientism, taking numbers for granted; and what two historians referred to as "the rush to the recent." (Scranton \& Fridenson, 2013)

\section{Expanding Progressive Sentiment}

It would be difficult to imagine developments that resulted in massive increases in facts being possible without a growing sentiment that new information could be used to correct corrupt practices by the private sector, such as adulterated canned foods or bogus medicines. The public came to appreciate the power of facts as a weapon to address society's ills and improve the quality of life (Gordon, 2016). New products, services, and laws based on scientific findings, as well as growing collections of social science data, could be used to address public ills. Investigatory reporting and research bolstered new social initiatives. Even in areas of the country where some of the least formally educated citizens lived, science encouraged improvements in quality of life, as has happened since the 1880s with agricultural extension agents traveling across rural America to teach farmers better ways of growing crops and how to reduce illnesses through improved sanitation (Conkin 2008; Duffy 1990).

\footnotetext{
${ }^{25}$ Crawford et al., (2015) on the case for sharing (pp. 5-26), and on the rising number of hoaxers, (p, 209-246); Broderick and Miller (2008), describing websites of information run by non-traditional experts, people not necessarily identified as knowledgeable about a topic by academics or recognized specialists working in government or business

${ }^{26}$ Some of the most widely read history books in the second half of the twentieth century were not written by historians working at universities. Think only of Tuchman (1966) and her history of the origins of the First World War, which may hold the record for being the most widely read book ever on the subject, or Catton (1953), who published widely read books on the Civil War, most famously $A$ Stillness at Appomattox for which he received the Pulitzer Prize in 1954.
} 
The national mood shift to a progressive sentiment is threaded through American history, for example, expressed during the Trump years in the political agenda of the progressive branch of the Democratic Party. Excesses of the Second Industrial Revolution's economy, combined with the rise of knowledge work and bodies of ethics, supported a national reform movement intended to address some of the more extreme negative consequences of the new economy. Fact-checking became more sophisticated as it became increasingly based in institutions and carried out by professionals, in newly established regulatory agencies, and in a new investigatory turn in journalism and academic research. Debunking and calling out excesses became a mainstay of American life, not the exception that it had been in earlier times.

During the harsh days of late-nineteenth-century economic activity, political and reformed-minded Populists accused government at all levels of aiding the rise and economic power of large banks, railroads, and other enterprises - often called the Trusts — which were seen as monopolistic and oligarchic commercial empires, ruthless against competitors, and for the most part oblivious to the needs of their workers. Boisterous Populists saw corruption everywhere; at the same time, the economy experienced bouts of recession. Then came the calmer Progressives, who wanted more government regulation of economic activity, in contrast to the Populists' call for less government. Progressives won the argument at the end of the $19^{\text {th }}$ century, and in the early decades of the new century won out with their calls for more government regulation of business excesses. Historian Jill Lepore neatly summarized the consequences of the Progressives' rise to power: "In the first decades of the twentieth century populism would yield to progressivism as urban reformers applied the new social sciences to the study of political problems, to be remedied by the intervention of the state." (Lepore, 2018). Not until the rise of the public Internet in the 1990s was there another era that so inspired fact-checking.

In the 1880s, as reporters flushed out facts and investigated harmful situations, journalism came into existence as a profession. Editors gained considerable exposure from journalists in as much as sales of newspapers kept rising over the next half century until the Second World War. An assemblage of these reporters came to be recognized in the Progressive Era as muckrakers. ${ }^{27}$ From the 1890s until 1930, they pursued corruption and conducted what today one calls "investigative reporting". Many of these muckrakers became well recognized reporters, social commentators, or political leaders, including Ray Stannard Baker, Lincoln Steffens, Ida M. Tarbell, Upton Sinclair, Frank Norris, Drew Pearson, and Charles Edward Russell.

Reformers called for the use of information as a weapon in their fight. In 1893 the famed lawyer Clarence Darrow exhorted on the pages of a leading reform publication that

\footnotetext{
${ }^{27}$ The term originated largely with President Theodore Roosevelt, who embraced investigatory reporters. In a speech made on April 14, 1908, drawing on a character from John Bunyan's book, Pilgrim's Progress (1678) [reprinted, New York: Dover, 2013], he spoke of "the Man with the Muckrake" who always looked down raking up "the filth of the floor." He praised investigatory reporters for drawing people's attention to the ills of society that needed to be addressed: "I hail as a benefactor every writer or speaker, every man who, on the platform, or in book, magazine, or newspaper, with merciless severity makes such attack, provided always that he in his turn remembers that the attack is of use only if it is absolutely truthful," Theodore Roosevelt in Wayne Andrews (ed.), The Autobiography, Condensed from the Original Edition, Supplemented by Letters, Speeches, and Other Writings (New York: Charles Scribner's Sons, 1958), 246-247. These reporters were soon known as muckrakers, a term they initially considered pejorative.
} 
"the world has grown tired of preachers and sermons; to-day it asks for facts. It has grown tired of fairies and angels, and asks for flesh and blood." (Darrow, 1893) Facts had power; they were regarded as being as realistic as science. The well-known social reformer of the 1890s, Jacob Riis, declared. "ours is an age of facts" and "it wants facts, not theories, and facts I have endeavored to put down [on paper]." (Riss, 1892).

Facts were seen across all sectors of society as an important component of modern American life. The conversation turned on the notion of realism. Staged photographs were challenging people's beliefs that a picture was real. In fiction, realism became popular, spilling over into nonfiction, such as that produced by a new breed of investigatory journalism (Orvell, 1989). New topics of currency included the rising numbers of immigrants, expanding cities and towns, and labor agitation - all of them challenging the agenda of an older order of elites.

Much of the conversation centered on the definition of modern culture. Was it the great literature of the ages, classical music, Victorian furniture, and traditional roles for workers and women? Charles Dudley Warner, newspaper editor and writer of fiction and nonfiction, a scion of the establishment having difficulty facing new realities and in defense of an earlier time wrote: "Do not misunderstand me to mean that common and low life are not fit subjects . .. or that vice is not to be lashed by the satirist ... or that the evils of a social state are never to be exposed [in literature]." By contrast, the younger Hamlin Garland wrote: "You have no sympathy with the American people or middle condition ... From your library, or from the car-window, you look upon our life; that is the extent of your knowledge of our conditions, at best." (Orvell, 1989, pp. 105-106). In the 1890s Garland's generation wanted more than just to make it proper for the poor to be literary characters, they were advocating for a political and social agenda that called for understanding the new realities using the same methods and facts employed by social, political, and business elites.

The fact-based work of the muckraking journalists examined corporate misbehavior and political corruption as well as other socially focused issues such as urban poverty, unsafe working conditions, child labor, and unsafe food, and other social/moral issues such as prostitution (Filler, 1976; Gallagher, 2006; Cook, 1972; Wilson, 1970). Their work called for reform, which squared with the political and social agendas of the Progressives. Their work appeared not only in newspapers, but also in widely read magazines, including Collier's Weekly, Munsey's Magazine, and McClure's Magazine. At the turn of the century, these investigative journalists received wide attention. Notable among them was Ida M. Tarbell's writing on Standard Oil, Lincoln Steffens on government corruption, and Ray Stannard Baker on working conditions. Their investigatory publications were often serialized and later collected into book form. ${ }^{28}$

This genre of reporting stood in contrast to the more widely diffused "yellow journalism" of the day, which was the kind of reporting that had existed for a century but had reached a fever pitch of sensationalism in the late 1800 s and was characterized by exaggerated facts, outright lies, and lack of objectivity. The muckrakers were instead about fact-based reporting. Riis reflected the emerging middle class value in objectivity and in facts

${ }^{28}$ Ida M. Tarbell, The History of the Standard Oil Company (1904); Lincoln Stephens, The Shame of the Cities (1904); and Ray Stannard Baker, largely in McClure's Magazine and The American Magazine. Others included Edwin Markham, Children in Bondage (1914); The Jungle by Sinclair (1906); and Ida B. Wells, On lynchings (2014, comprising three books published 1892-1900). More generally on the muckrakers, see The Muckrakers by Filler (1976); The Muckrakers by Gallagher (2006); The Muckrakers by Cook (1972). 
as something to have faith in when shaping modern society. ${ }^{29}$ One historian summed up debates of the 1880s-1890s: "Resistance to the power of 'fact' came from the genteel establishment, which associated facts with science and viewed both as threats to the established order of conventions and assumptions." (Orvell, 1989, p. 107) Professors, government researchers, and non-political staff increasingly sided with science, placing great value in facts and in the use of the scientific method to solve society's ills.

Muckrakers represented the full flowering of investigative reporting that had started just before the Civil War when, in 1858, Leslie's magazine published one of the first muckraking type of stories. It reported that thousands of babies in New York were dying of diarrhea because of sales of "swill milk", from miasmic dairy cows being fed leftover mash from local whiskey distilleries. The story reported how the issue had arisen in the 1830s and presented illustrations of local barns and facilities where the swill came from. In 1862 the New York state legislature passed its first milk regulation, a halfway step until pasteurization and rail transport made it practical to bring fresh milk to New York (Duffy, 1968).

Food safety was an issue of growing interest following the Civil War, as the cattle industry grew. Refrigerated railroad cars could transport butchered meat across the United States, but reports of food safety raised concerns. The issue came to a head when Upton Sinclair published his novel, The Jungle, in 1906, which was a thinly veiled expose. He investigated practices of the meat-packing industry although he was not a journalist. While his focus was on unsafe working conditions, it was obvious to readers that food safety was just as big of a problem. Historians paid particular attention to Sinclair's book because it influenced the establishment of the Food and Drug Administration (FDA), beginning with the passage by Congress of the Food and Drug Act and the Meat Inspection Act in 1906 (Law \& Libecap, 2006). Attention focused on improving sanitary conditions and avoiding food-borne illnesses. ${ }^{30}$

Sinclair described working-class poverty and the nearly complete lack of public assistance to the poor in his meatpacking industry case study. Other investigative reporters followed up, with newspaper stories and photographs of meat-packing plants graphically illustrating the unsanitary conditions. ${ }^{31}$ While remaining faithful to truth, Sinclair used the style of the novelist to heighten his persuasiveness. Consider how he described the smell of stockyards: "It was an elemental odor, raw and crude; it was rich, almost rancid, sensual, and strong." ${ }^{32}$ Regarding the dump where discarded cattle body parts were disposed, he wrote: "here was a great hole, perhaps two city blocks square, and with long files of garbage wagons creeping into it. The place had an odor for which there are no polite words; and it was sprinkled over with children, who raked in it from dawn until dark." (Sinclair, 1920, p. 33) He detailed how meat packers butchered and processed the hogs, speaking of the animals" "wails of agony ... it was too much for some of the visitors. ... They slit their throats ... it was pork-making by machinery, pork-making by applied mathematics.” (Sinclair 1920, p. 40)

\footnotetext{
${ }^{29}$ A key point made by Schiller's (1981) Objectivity and the News: The Public and the Rise of Commercial Journalism) and of continuing concern all through the twentieth century, for example, Silverman's (2007), Regret the Error: How Media Mistakes Pollute the Press and Imperil Free Speech

${ }^{30}$ Home economists employed by state universities had started in the 1870 s to increase awareness about sanitary practices among women all over the United States that contributed to the increased concern about food safety in general Cortada, (Cortada, 2016, pp. 206-208).

${ }^{31}$ See, for example, photographs from "1900 in Chicago," Library of Congress, Geo. R. Lawrence Co., photographer. http://hdl.loc.gov/loc.pnp/pan.6a34701

${ }^{32}$ Upton Sinclair, The Jungle, all quotes from 1920 edition, 28.
} 
Sinclair described both the killing process and the processing of cattle in graphic detail. Later, he reported: "For it was the custom, as they found, whenever meat was so spoiled that it could not be used for anything else, either to can it or else to chop it up into sausage," launching an entire chapter about "the spoiled-meat industry" showing how packers used "everything from a pig but the squeal." (Sinclair, 1920, p. 160)

The public responded to Sinclair's and other reporting by calling for increased regulation, specifically for inspectors to monitor sanitary operations and enforce regulations. In 1906, the regulation began with prohibitions against the buying and selling of food, drinks, and drugs that were mislabeled (addressing patent medicines) or tainted (addressing meats and other foodstuffs). Regulation expanded beyond meat packing to drugs and other issues of food production as the twentieth century unfolded. In 1930, the FDA assumed its current name, although its subsequent focus was primarily on drugs.

From the beginning, the FDA employed chemists and other food experts to test the quality of foods and report on dangerous or illegal conditions and acts of mislabeling. For example, the FDA insisted Campbell's add pork into the cans of its famous Pork \& Beans canned product. The company complied because the product was too popular to abandon. The FDA was a fact-based operation from its beginning, using scientifically derived facts as its principal weapon. Science, it turned out, was a protector of the FDA, which was often challenged in court by drug companies with much larger staffs (Young, 1961).

Ida M. Tarbell provided another example of the new form of fact-checking during the Progressive Era, with her publication of The History of The Standard Oil Company (1904), which describes the oil industry's ruthless practices. Like Sinclair, she described the industry practices in detail and reached similar conclusions: "Our national life is on every side distinctly poorer, uglier, meaner for the kinds of influence he [John D. Rockefeller] exercises (Tarbell, 1904)." Her book provided the factual and political impetus to break up Standard Oil under the Sherman Anti-Trust Act, passed in 1890. This law was commonly used by the government against monopolistic behavior over the next century. Tarbell's investigative reporting inspired a generation of journalists to explore a wide-ranging set of problems in American society based on facts, rather than argumentation. Her preface set the tone of her investigation:

In order that their readers might have a clear and succinct notion of the processes by which a particular industry passes from the control of the many to that of the few, they decided a few years ago to publish a detailed narrative of the history of the growth of a particular trust. The Standard Oil Trust was chosen for obvious reasons. It was the first in the field, and it has furnished the methods, the charter, and the traditions for its followers. It is the most perfectly developed trust in existence .... (Tarbell, 1904, vii).

Tarbell based her research on testimonials, legal documents, public reports and pamphlets, and interviews. She offered a history of the firm and its industry. One chapter after another, the study builds up the case, identifying behaviors, incident-by-incident, offering facts about who was involved, when, where, and why. The book's many photographs were almost all portraits of the leading protagonists; so, Tarbell did not yet practise the form of fact-checking photojournalism that would become common practice from the 1930s. 
Much of Tarbell's evidence came from direct testimony of the various stakeholders. For example:

A former official of the Empire Transportation Company, who in 1877 took an active part in the war his company was waging against the Standard, once told the writer that in every town, North or South, East or West, in which they already had a market for their refined oil, or attempted to make one, they found a Standard agent on hand ready to undersell. The Empire was not slow in underselling. It is very probable that in many cases it began it, for, as Mr. Cassatt says, "They endeavored to injure us and our shippers all they could in that fight, and we did the same thing." (Tarbell, 1904 pp.188-189)

She continued:

At the beginning of the fight he had very shrewdly enlisted in his plan one of the largest independent producers of the day, B.B. Campbell, of Butler. "Being a pleasure and a duty to me," says Mr. Campbell, "I entered into the service with all the zeal and power that I have. I made a contract with the Empire Line wherein I bound myself to give all my business to this line." (Tarbell, 1904, pp. 189)

Tarbell's narrative style was adopted throughout the next century by both investigative reporters and government investigators doing similar work.

Newspapers did the greatest amount of fact-checking in American society in the half century before the Second World War, employing individuals to catch errors before publication. Proofreaders had been used since before the Civil War. Magazines also had entire departments doing this kind of work by the end of the 1920s. Reporters did not always welcome fact-checkers since they seemed to them to be "knick pickers." (Graves, 2016; Silverman, 2007). Mass communication professor Lucas Graves has made a key point about media fact-checking that did not change until the Internet era: "It takes aim at the reporter, not the people being reported on. When a news outlet insists on verifying a source's claims instead of simply reporting them as claims, the choice upon discovering a mistake has usually been to fix it or to cut it." (Graves, 2016)

As computers came to be used in higher education and in libraries, users of the technology began building files of data that they could access to fact-check findings in a scientific manner, identify sources of information, and model physical realities (such as weather) (Baker \& Jeffries (1976). ${ }^{33}$ Those embryonic approaches to the use of computer files began in the 1960s and gained attention in the 1970s across multiple disciplines. These uses were less about fact-checking and more about data access. We can regard the academic's routine use of books to check their assertions as a form of fact-checking that slowly ported over to computers prior to the arrival of the Internet.

These issues were sufficiently widespread that Hollywood could even make a movie about this topic, Desk Set, released in 1957, with two high-profile actors, Katharine Hepburn and Spencer Tracy, as the protagonists in this romantic comedy. Hepburn played the role of a long-established fact-checker for a broadcast network, using the well-honed skills of the

\footnotetext{
${ }^{33}$ Computers in Humanistic Research: Readings and Perspectives (Bowles, Ed., 1967) discussed the use of computers in such fields as anthropology, history, political science, language and literature. Lawyers were early users of databases (Freed, 1967; Murray, 1977; Vital Speeches, 1977; Business Week, 1965).
} 
librarian. She believed she was about to be replaced by an IBM computer to do the same work. Of course, as needed in a comedy, the computer mistakenly fired everyone in the company and only humans could fix the problem. The movie addressed a growing fear in American society that this new technology might destroy jobs at the same time it was creating greater capabilities to find and use facts (Bix, 2000). As the movie illustrated, a new era of fact-checking was unfolding with the arrival of computers, and concomitant with it was a fear of job loss through automation.

A core of experts in the creation and use of new information in the natural and social sciences taught millions of students how to view facts critically, measure phenomena, and explain rationally what they had observed even before making decisions and taking actions. Table 3 presents both the kind of data one became accustomed to receiving from the American government and statistical evidence of how many doctorates were awarded in the natural sciences during the formative period in the development of experts. That fifty-year period set a pace that was significantly exceeded after 1970. The lesson from this table is that America rapidly expanded the number of fact creators versed in scientific and statistical methods, who in turn taught their ways and their facts to millions of people working throughout industries and society more generally.

Next consider Table 4, which tabulates similar data for doctorates in the social sciences. Many of the information-handling practices evident in the natural sciences now transferred over to fields that even as late as the 1870 s created few if any doctorates in the United States, and only a handful of doctorates for Americans awarded by Europe institutions. ${ }^{34}$ As with the data in Table 2.3, the number of degrees conferred grew at a much faster rate than the nation's population.

\section{TRANSFORMED MEDIA INDUSTRIES AND PROFESSIONS}

As journalists became better educated and had more reliable data to work with, they and their readers came to expect more factual, unbiased reporting. Although reporting continued that was more about reporting a position than telling the truth, as in the case of newspapers advocating war against Spain in the 1890s, muckrakers were busy at work reforming journalism. By 1900, the nation's sentiment had shifted sufficiently toward fact-based reporting. Formal university education in journalism had become available and embraced the value of accuracy. ${ }^{35}$ Medical doctors responded to criticism of their performance during the Civil War by expanding formal medical training and professionalism, largely put in place by the 1920s. Accountants and financial experts introduced statistics and cost accounting, as well as data processing equipment such as adding machines, calculators, and punch card equipment, into their professional work (Levenstein, 1998; Bud-Frierman, 1994). When radio and television became widely available, in the 1920s and 1950s, respectively, the American

\footnotetext{
${ }^{34}$ Historians credit the arrival of modern, more scientific approaches to their craft to German historian Leopold Ranke (1795-1886), according to Breisach (1994).

${ }^{35}$ The first major in journalism was established at Washington \& Lee University in 1869 by its president, Robert E. Lee, who had between the senior military commander during the Civil War for the Confederacy, while other schools began offering specialized courses in the late nineteenth century. Several of these efforts evolved into entire schools of journalism, including the Missouri School of Journalism, established in 1908, and those at Columbia, University in 1912, CUNY in 1961, and Berkeley in 1967. Courses were taught in various departments, for example, by political science professors at the University of Wisconsin-Madison beginning in the 1920s.
} 
government established regulations that ensured balanced reporting of political events, defined in terms of equal airtime for opposing positions (Slotten, 2000). ${ }^{36}$

Together, these developments created a dense American data infrastructure that served as a bulwark against folk wisdom, lies, misinformation, and badly executed research. Factchecking in the creation of the nation's information infrastructure was less about going after falsifiers and more about ensuring that researchers and reporters got their facts correct.

Books were another part of the American information infrastructure. Consider 1880, 1900, and 1916-years when both the population of the United States and school attendance were growing. Children's books increased from 270 to 527 to 670 new titles published. When all fiction and nonfiction children's and adult titles are combined, the number of new titles increased from 2,076 to 6,356 to over 10,000 in these same years. In 1917, when the country entered the First World War, there were in excess of 50,000 new titles. That number grew to over 300,000 new titles per year by 2000 (Cortada, 2016, p 35). ${ }^{37}$

Newspapers were another important component of the information infrastructure. By the time of the Civil War in 1860, the approximately 1,000 U.S. newspapers provided a circulation of 3.5 million copies. Most of these papers were read aloud in country stores, taverns, hotels, and post offices, so more than 20 million people routinely "heard" the news (Cortada, 2016, p. 58). In 1880, of the 2,605 counties in the United States, 2,073 had a local newspaper; that statistic did not include 7,400 specialized publications and magazines (Kaestle, 2007). The trend in expanded circulation and the variety of newspapers available continued throughout the twentieth century. Table 5 points to the essential finding of this discussion: a great deal of information was routinely and affordably available to the majority of residents. Note that, as new technologies for transmitting information became available, these typically supplemented rather than supplanted existing news sources, making for a dense information ecosystem long before the arrival of the personal computer, smart phone, and the Internet. ${ }^{38}$

Another trend - often overlooked by historians but highly visible to the public - was the role of magazines. We have argued that the largest battleground over truth versus misinformation in the public's attention was the newspaper, especially before the First World War. Magazines, which had begun to be published in America in the eighteenth century, entered the story about the search for accuracy in public information in the second half of the nineteenth century. Magazines represent a compromise between the book and the newspaper in terms of the time allowed for their production, the detail they could go into, and their shelf life with consumers. Magazines were used to examine more complex issues than newspapers could cover well, such as economic trends, developments in science and medicine, and the role of evolving fashions. Throughout their history, American magazines have also published fiction and poetry, often written by accomplished writers.

Magazine editors understood that their readers were better educated and more discerning than newspaper readers on average; and the magazine editors tried to provide more accurate stories. Newspapers, by contrast, met the need of providing immediacy, but they were transitory and did not always have the luxury of time to explore the fullness of a topic. A

\footnotetext{
${ }^{36}$ Discussion of regulatory options began years earlier, according to Slotten (2000).

${ }^{37}$ For further details, see (Cortada, 2016, p. 35).

${ }^{38}$ For discussion about what they did with all these information tools, Cortada, 2016, pp. 373-382).
} 
veteran of the magazine industry, writing in the late 1940s, discussing truth and by inference fact-checking, noted:

The individual and the social group are assailed, and sometimes almost overwhelmed, by facts and fiction, by fantasies labeled fantasy, and by other fantasies labeled fact. Truths, partial truths, distortions, mistaken convictions, and deliberate falsehoods confront us everywhere in print and in broadcast speech (Wood, 1949).

Magazines, the same writer argued, had to avoid "special pleadings" or lose their readers. As education levels increased, so too did the need to deliver accurate facts: "The magazines of the mid-twentieth century can hold their huge circulations with serious discussions which would not have been tolerated by the magazine audiences of 1910 or even 1930." Readers were "a fact-hungry audience which has learned to evaluate facts and their significance, to form its own opinions, and to judge those proffered by magazine writers." 39

Magazines first became popular in the eighteenth century. Some, for example, the Saturday Evening Post, founded in 1821, lasted for over a century. It published many articles of interest to women, including fiction and human-interest stories, and quickly it became one of the most widely read magazines of the mid-nineteenth century. While it covered weighty topics, its editorial policy was to be "neutral in politics." Over the next century, the quality magazine industry established a tradition of publishing carefully vetted factual articles. By the 1920s, high schools were using magazines to teach writing, critical thinking, and history. A common choice of the schools was the Literary Digest, which employed editors who challenged facts offered by its writers and who also had staff checking the authors' claims. In the mid-twentieth century, The New Yorker may have had the most stellar reputation for factchecking, but its competitors acted similarly (Wood, 1949, p. 187, 212). During the 1930s, the business magazine Fortune became a trusted source of facts. Staff reporters wrote its articles and, as one industry expert from the period noted, its articles were "the product of thorough and extensive research. A staff of women researchers does an exhaustive job of file research. Staff writers or their assistants' interview anyone and everyone who can give them the facts that they need to know in order to present a full and accurate picture." (Wood, 1949, p. 192)

The rise of large corporations, government agencies, universities, national newspapers, and later radio and television stations - all keen on nurturing good reputations - reinforced the fact-checking standards of the magazines. By the early twentieth century, public relations had become a profession with its own ethics, practices, and importance. A fact-checker's legitimacy, hence acceptance, became increasingly tied to the reputation of the organization for which he or she worked. Business management professors think of this as yet another example of socially constructed processes: "legitimacy emphasizes the social acceptance resulting from adherence to social norms and expectations," while "reputation emphasizes comparison among organizations." (Deephouse \& Carter 2005) Legitimacy and reputation linked together (Meyer \& Rowan, 1997; Pfeffer \& Salancik, 1978; Carroll \& Hannan, 1989; Shrum \& Withnow, 1988; Hall,1992; Weigelt \& Camerer, 1998). A positive reputation contributed to a sense that what an organization says, and what its fact-checkers report, is authentic, real, and truthful (Deephouse \& Carter 2005, pp. 331-332).

\footnotetext{
${ }^{39}$ See Wood (1949, p. 287). As early as 1741, Benjamin Franklin recognized this value of magazines, when he launched his widely read General Magazine. It was a magazine, not a fat newspaper. Its issues routinely ran to 75 pages, carried fact-based articles on weighty issues such as the currency (think economics before that word was used), book reviews, theology, poetry, and history.
} 
In addition to fact-checking of books and magazines, the professionalization of science in the late nineteenth century led to the process of specialty scientific publication and peer review. Formal education, including research universities, was on the rise, leading to a more discriminating audience. ${ }^{40} \mathrm{~A}$ number of occupations - including medicine, elementary school teaching, agricultural information services, home economics, and journalism - were professionalized in the late nineteenth century, and these professionals acquired more discriminating cognitive skills as part of their work. Agencies of the federal government had information-creating agencies, which followed these practices of research and accurate reporting.

As new academic disciplines emerged, their experts formed academic associations. The American Medical Association was an early entrant in 1847, but dozens of others followed before the First World War, for example: the American Historical Association (1884), American Economic Association (1885), American Institute of Electrical Engineers (1888), American Mathematical Society (1888), and the American Political Science Association (1903). As new academic fields developed in the twentieth century, they established one or more similar associations, which became the guardians of their disciplinary values, including policing how research was done. Members of academic associations controlled how university-level scientists led fact-based production of information and how academics were trained. These organizations managed key academic journals and populated university presses with editors, authors, and customers.

In the late 1800 s, universities in collaboration with academic associations began to dominate the publication of new facts in the natural sciences, social sciences, and humanities. From the 1880s to just before the First World War, leading universities launched one or more academic journals: the University of Chicago (12), Harvard University (8), Columbia University (6), Cornell University (5), and University of California (4), and smaller numbers of journals from a dozen other educational institutions - for a total of 54 scholarly publications (Geiger, 1986, pp.32-33). These academic publications were an outward manifestation of a large surge in the higher education enterprise, which was training high school and college students in the norms of creating and evaluating facts. ${ }^{41}$

The breadth of topics expanded as associations, such as the American Economic Association and the American Historical Association, joined the universities in peer-reviewed publishing. Journals appeared on a variety of topics: philology and humanities (25), social sciences, economics, and law (4 each), biology and hard sciences ( 3 each), and mathematics (2), among others (Cortada, 2016). Government and industry also followed suit, in publishing peer-reviewed journals. Perhaps the most famous of these government publications was the Monthly Labor Review, established in 1915 (Dupree, 1957). All of this happened prior to the postwar boom in academic publishing beginning in the 1950s.

Before closing the discussion about the role of professionals, additional context regarding the behavior of professions reinforces the broad underlying theme that the nation looked for order in both its information and how it was used. The subject of how professions developed has now been the subject of much study for over a half-century, with significant

\footnotetext{
${ }^{40}$ We particularly had in mind developments from the late 1800s until the Second World War, when the norms were established that continued into the twenty-first century. For details, see Geiger (1986).

${ }^{41}$ For a discussion of the number and distribution by academic discipline advanced degrees, see Cortada (2016).
} 
detailed examination of their behaviors well documented. ${ }^{42}$ Most of these professions, and particularly the academic disciplines, and medicine, library science, economics, and business among others evolved under contentious circumstances. They debated what truths (facts) were relevant to their work, whether or not they should be, and were applying basic scientific methods of discovery, theory and analysis, what constituted accreditation or licensing, and always there were the politics and economics of prestige and market control. Dentists did not want barbers pulling teeth, librarians sought to be seen as scholarly and academic, business professors regarded their work as scientific, and so it went over the course of the past 150 years and across nearly 200 professions. But in those professions that have been studied, many of these behaviors were present. The tensions about the definition of professions, what information they relied upon, and validation of facts were common features, shaping the way cross-currents existed in American society. ${ }^{43}$

We close this discussion about the diffusion of accurate, useful information, by considering patents and copyrights, which measure the intellectual end products of practical learning. In 1946, the US Patent Office received 81,056 patent applications and issued 21,805 patents. By 1986, that office received 122,433 applications and issued nearly 71,000 patents. As of 2006, just before Apple introduced the smartphone (which set off a new round of patenting), patent applications reached 426,000 and 174,000 patents were issued. ${ }^{44}$ The growth in copyright was similar: in 1946, 202,144 copyrights were issued; in 1986, 560,000; and in $2006,656,000 .{ }^{45}$ Underlying these activities was tremendous information creationvetted initially through academic and professional association channels, then by lawyers and government officials engaged in the patenting and copyrighting processes. The United States led the world in the creation of information for most of the twentieth century. ${ }^{46}$

Of course, for many years people had sought information not only through the reading of books and newspapers. They learned from teachers, ministers, relatives, and friends, as well as from a growing list of experts who walked through their lives, ranging from county agricultural extension agents to doctors, lawyers, business consultants, and other subjectmatter experts (Kett, 1994; Cortada, 2016, pp. 344-362).$^{47}$ In the process, Americans learned whose information to value: trusted neighbors, friends, and family; distinguished news outlets such as the New York Times or Washington Post; accreditation associations and government licensing agencies.

The general public's concerns still exist today, as we learn from survey data. In 2018 the Pew Research Center, a widely trusted source, reported that nearly two-thirds of Americans who have heard of media bots believe they have been used "maliciously." This is problematic inasmuch as two-thirds of the surveyed population believed people receive "a fair amount" of their news from such sources and thus these "have a negative effect on how the

\footnotetext{
${ }^{42}$ Wiebe (1967) began the modern discussion with his book, The Search for Order, 1877-1920, next followed up by Freidson's (1986), Professional Powers: A Study of the Institutionalization of Formal Knowledge and by Abbott's (1988), The System of Professions: An Essay on the Division of Expert Labor, and extended by another sociologist, Freidson's (2001), Professionalism: The Third Logic .

${ }^{43}$ For an extensive discussion of such matters, Cortada (2016), includes an extensive bibliographic essay.

${ }^{44}$ U.S. Patent and Trademark Office.

${ }^{45}$ Annual Reports of the Registrar of Copyrights (Washington, D.C.: Library of Congress).

${ }^{46}$ Between 1900 through 1970, American citizens or permanent residents received 126 Nobel Prizes. Of all Nobel prizes awarded between 1901 and 2013 worldwide, the number of laureates who lived in the United States was 876 and 350 respectively.
} 
public stays informed." Stocking (2018). ${ }^{48}$ President Thomas Jefferson had made a similar observation about newspapers in the early 1800 s.

\section{A Data and Computing Infrastructure}

The availability of commercial computers beginning in the 1950s and their connection via telephone lines and other dedicated telecommunications networks beginning in the 1960s enabled new ways for fact-checking to take place - even though the techniques themselves used by fact-checkers did not change. New information technologies did not replace the interview, or fact and paper-based research and reporting techniques adopted by journalists and academics that had been honed over the previous century. It would be easy to exaggerate the extent of computing's role in fact-checking before the wide public use of the Internet since the late 1990s.

When computers became available as commercial products in the 1950s, they were expensive and had limited processing power and storage. Large organizations and companies used this technology for such activities as calculating and printing paychecks, performing accounting functions, tracking inventory, and scheduling work in factories. Engineers appropriated computers to design complex equipment, such as aircraft and rockets that required extensive mathematical calculations, activities that these machines could perform. As the amount of digitized data that could be stored in a computer increased rapidly in the 1950s and 1960s, new data-intensive uses became possible, most spectacularly in weather forecasting, space research, and modeling of other natural phenomenon. Meanwhile, computers dropped in cost and increased their calculation speed and information storage, making it feasible to incorporate them into additional organizations that collected and studied information in bulk. These included universities, data-rich government agencies (e.g., Census Bureau, Department of Commerce), and, by the end of the 1960s, publishers (of newspapers, magazines, and books) and law offices. Media companies used computers largely to reduce their costs of producing text and publishing. The various organizations that conducted factchecking before computers had the ability to move information - using the telegraph since the 1860s, teletype since the 1910s, and computers over telephone lines since the 1960s. Little changed until two things happened.

By the early 1970s, large data files could be accumulated and accessed with software, making it possible to search and study digital files that could be transmitted from one machine to another. Personal computers first became available in the late 1970s and in larger quantities in the mid-1980s. By the end of the 1980s, tens of millions of PC users could now connect their microcomputers to others and to large computers housing expansive data files, using telephone lines by connecting service providers such as Prodigy and CompuServe (CampKelly et. al., 2014; Campbell-Kelly \& Garcia-Swartz, 2015). Private networks had already started to serve academic researchers, news reporters, even high school and college students as early as the 1960s (Rankin 2018). After the breakup of AT\&T in 1984, innovation flourished and over the next half dozen years new telecommunications technologies made it possible to transmit together text and images, while new software made it more attractive and easier to gather and analyze information. ${ }^{49}$ This construction of a national ad hoc ecosystem

\footnotetext{
${ }^{48}$ Stocking (2018). With bots spreading rapidly and becoming more effective (i.e., realistic) they represent a growing challenge for truth seekers (Shao et al., 2018)

${ }^{49}$ In the spirit of reducing confusion, a federal judge ordered the breakup of AT\&T in January 1982, but it was not until the start of 1984 that the order was actually carried out.
} 
composed of networks and computing in enterprises from large corporations to one's home office presaged the remarkable innovations of the Internet in the mid-1990s. In this preInternet era, people could create digital communities of practice, an ecosystem in which they could share information, correct factual errors, and assist one another (Brown \& Duguid (2017).

Networked computers emerged in this period in a parallel universe largely for academics, defense contractors, and the military, but it was a small operation prior to the early 1990s. As late as August 1981, when IBM introduced its PC in response to demand for desktop computing, there were only 213 host computers connected to the Internet, each typically serving a few dozen terminals. It took another four years before the number of computers on the net surpassed 1,000. In the late 1980s, connections to the Internet took off: 18,000 by the end of 1987, 159,000 two years later, and 1.1 million in 1992. Over the next two years, an additional two million computers joined the Internet, and in 1994 - the year historians tend to peg as when "everyone" embraced the Internet - nearly 4 million computers were connected. However, the growth continued. By the end of 1996, the number had grown to 16 million; and two years later, the United States achieved 30 million connections (Greenstein, 2015). So, through the 1980s, the bulk of fact-checking with any use of computing was effectively restricted to the same institutions that had conducted that activity for decades without benefit of digital computers (but using older technologies such as telegraph, telephone, teletype, and fax); and fact-checking had not yet become a practice of individuals.

In the 1970s, publishers began to sell electronic products, initially electronic copies of books and magazines - and even encyclopedias - on CDs. By the end of the 1980s, frequently updated newspaper reports and sets of data began to be accessible from one's personal computer. By the early 1990s, there was a new mindset about large collections of information. As the chairman of book publisher Simon \& Schuster, Richard Snyder, explained: "We sell information in any form, in any way you want it," adding, "we are out of the confines of print, although that doesn't mean we are out of the print business. We now sell the same information in various forms (Weyr, 1992)." Databases that could be accessed by factcheckers included online copies of entire runs of newspapers and magazines, government databases (providing census, economic, and social data), and weather and other scientific databases provided by both government and academic institutions. At the same time, companies were making available to their employees online massive databases created by the companies and used by them to help manage their operations, companies and accounting firms. ${ }^{50}$

Government databases had existed since the early days of networking and, over time, became accessible through the Internet. These included ERIC (Education Resources Information Center), created and populated with massive quantities of material by the US National Library of Education beginning in 1966, and CRIS (Current Research Information System), hosted by the US Department of Agriculture for decades, along with Agricola maintained by the US National Agricultural Library since 1970. By the late 1980s, there were

\footnotetext{
${ }^{50}$ Law firms were early adopters, to conduct legal research and find evidence and arguments to counter those of others in contested lawsuits, using such tools as LEXIS and WESTLAW. For details, see Computer Aided Legal Research by Long (2003); New Wine in Old and New Bottles: Patterns and Effects of the Internet on Companies," by Cortada (2008).
} 
so many government databases that guided to them were being published. ${ }^{51}$ Other major providers to fact-checkers included the proprietary database Lexis-Nexis created in 1970, long the mainstay research tool of lawyers; Dow Jones News/Retrieval Service, created in 1973, used largely by academic and media researchers; and Dun \& Bradstreet, created initially in 1963 as an online system but soon expanded to include news and business information. These new commercial entrants continued a tradition of private information vendors offering large collections of facts that had existed prior to the First World War (Friedman, 2013).

The Internet became useful to fact-checkers through three developments: nationwide networks with terminals attached to them; rapidly growing bodies of digitized information that could be called up, downloaded, manipulated, compared to other bodies of data, and reorganized and presented quickly and easily; and email, which became widely available by the early 1990s. For PCs, two additional tools helped enormously: spreadsheets into which numerical and later textual data could be imported from other databases, and database management software to organize numerical and text files. Millions of people had become familiar with PCs, emails, spreadsheets, and database management tools by the time the Internet was widely accessible. Service providers had also been available for more than a decade, for example, Prodigy since 1979. By 1990, Prodigy had almost a half-million subscribers, while its archrival, CompuServe, had 600,000. Both transformed into Internet service providers (ISPs) in the 1990s. Several million early users of the Internet could access these and other databases to conduct their work (Greenstein, 2015, pp. 222, 232).

The volume of facts that now could be computerized, manipulated, searched, distributed, and managed grew well beyond the magnitude that a human could handle or store in a paper collection. Computer vendors began to talk about how, with technological advancements, all the information in the Library of Congress could be put into small cabinets and later into a handful of computer chips; and that if all the data in a computer were printed out, the document would span the distance between the Earth and the Moon, yet all of this could be moved about in the back of a pickup truck. The significance was that a handful of fact-checkers working in the back room of the New Yorker or at the Washington Post could now handle many times more work in a more accurate fashion (or the number of workers could be reduced provided that the material they were working with had been computerized) ${ }^{52}$ Moreover, as historian Jill Lepore noted, computers created "the elimination of time" by exceeding human performance speed and reading, if one accepted the dark consequences to "the turning of citizens into pieces of data, fed into machines, tabulated, processed, and targeted, as the nation-state began to yield to the data-state (Lepore, 2018, p 527)."

One of the consequences of the use of the Internet that became increasingly obvious at the turn of the century was the ability of anyone to pronounce, to declare their perspective as truth, which is why the number of Internet-based fact-checkers took to the Net. A new frontier for discourse and the sharing of facts and falsehoods had opened up. It was digital, easy to access and widely adopted. A second consequence is that the primacy of experts that had been so widely developed in the prior century was now being challenged, weakening the value of their knowledge. It was becoming more difficult to differentiate between truth and falsehoods (Aspray \& Cortada, 2019, pp. 1-8). The culture of the expert was being destabilized. That

\footnotetext{
${ }^{51}$ See, for example, Online Database Search Services Directory by Maxfield (1988). Gale publishing has been one of the leading providers of such guides. This 1988 publication was already 1268 pages in length; editions from the 2010s were in 6 volumes.

${ }^{52}$ Quickly, practices emerged that optimized the technology, Graves, Deciding What's True, 8-10.
} 
process, of course, predated the Internet as mistrust of experts increased during the second half of the twentieth century with such signal events as university students critical of the pronouncements of the Nixon Administration during the Vietnam War, hostility of rural communities toward government officials and their experts, and the way in which major national crises were described and handled, from the assassination of President John F. Kennedy to the financial crisis of 2008. While fact-checking in any period never proved to be a linear one of progress, sped-up events with the assistance of the Internet made that observation more apparent.

\section{IN SUMMARY}

We have argued in this essay that six forces have led us to the place we are today in which scrutiny is alive and well and is practised not only in political fact-checking, debunking of urban legends, and evaluating the authenticity of cultural artifacts. These forces are: the rise of various forms of literacy; the rise of big government, especially government organizations driven by the creation and use of data; the rise of the natural and social sciences and their essential reliance on good data; the rise of progressivist thinking, which valued the importance of data and knowledge to make life better; changes in the media industries that led them to become more fact-based and to professionalize the work of fact-checkers; and the creation of a data and computing infrastructure that enabled both organizations and individuals to create, store, identify, and use pertinent data. By the late nineteenth century, all six of these cross-cutting themes were present in American society - and the use of scrutiny to thrive in an increasingly complex world has continued ever since. We also have pointed out that the practice of these cross-currents were not without their challenges, as none of them were implemented smoothly in some continuously improving fashion. But the key finding is that they existed, an important realization as the number of scholars studying the role of information in societies during the past two centuries increases. The American experience is one of those cases, but not the only one, but one already receiving a great deal of scholarly attention and so we suggest perhaps instructive for those exploring the experiences of other nations.

\section{REFERENCES}

Abbott, A. (1988). The system of professions: An essay on the division of expert labor. University of Chicago Press.

Aguayo, R. (1991). Dr. Deming: The American who taught the Japanese about quality. Fireside.

Alderson E., \& Harmon, A. (1934). Surveying for boy scouts with chapters on map reading. Brown \& Gerguson.

Andersen H., \& Hepburn B. (2015). Scientific method. In Stanford encyclopedia of philosophy. https://plato.stanford.edu/entries/scientific-method/

Aspray, W., \& Cortada, J.W. (2019). From urban legends to political fact-checking. Springer. Baker, B.A., \& Jeffries, J.C. (1976). The computerized librarian. Datamation, 22(12), 61-66.

Bix, A.M. (2000). Inventing ourselves out of jobs? America's debate over technological unemployment, 1929-1981 (pp. 242-243, 251-252, 274-276). Johns Hopkins University Press.

Blair, A. (2011). Too much to know: Managing scholarly information before the modern age. Yale University Press. 
Bowles, E.A. (Ed.). (1967). Computers in humanistic research: Readings and perspectives. Prentice-Hall.

Breisach, E. (1994). Historiography: Ancient, medieval, and modern (pp. 232-238, 255-269, 278-289). University of Chicago Press.

Broderick, J.F., \& Miller, D.W. (2008). Web of conspiracy: A guide to conspiracy theory sites on the Internet. Information Today, Inc.

Brown, J.S., \& Duguid, P. (2017). The social life of information (pp. 118-120). Harvard Business Review Press.

Brush, S.T. (1974). Should the history of science be x-rated? The way scientists behave (according to historians) might not be a good model for students. Science (new series), 183(4130), 1164-1172.

Bud-Frierman, L. (Ed.). (1994). Information acumen: The understanding and use of knowledge in modern business. Routledge.

Business Week (1965, January 23). When computers do the digging: Hunt through case and statute books, pp. 54ff.

Cajori, F. (1890). The teaching and history of mathematics in the United States. Government Printing Office.

Campbell-Kelly, M., \& Garcia-Swartz, D.D. (2015). From mainframes to smartphones: A history of the international computer industry (pp. 105-123). MIT Press.

Campbell-Kelly, M., Aspray W., Ensmenger N., \& Yost J.R. (2014). Computer: A history of the information machine (pp. 271-273, 290). Westview Press.

Carroll, G.R. \& Hannan, M.T. (1989). Density dependence in the evolution of populations of newspaper organizations. American Sociological Review, 54, 524-541.

Catton, B. (1953). A stillness at Appomattox. Random House.

Conkin, P.K. (2008). A revolution down on the farm: The transformation of American agriculture since 1929 (pp. 22-24, 60, 192). University of Illinois Press.

Cook, F. (1972). The Muckrakers. Doubleday \& Co.

Cortada, J. (2016). The facts: A history of information in the United States since the 1870s. Oxford University Press.

Cortada, J.W. (1983). Before the computer: IBM, NCR, Burroughs, and Remington Rand and the industry they created, 1865-1956 (pp. 1-88). Princeton University Press.

Cortada, J.W. (2008). New wine in old and new bottles: Patterns and effects of the Internet on companies. In W. Aspray and P. E. Ceruzzi (Eds.). The Internet and American business (pp. 391-421). MIT Press.

Cortada, J.W. (2008). The digital hand, vol. 3, How computers changed the work of American public sector industries (pp.184-210). Oxford University Press.

Cortada, J.W., \& Aspray, W. (2019). Fake news nation. Rowman \& Littlefield.

Crawford, H., Hunter, A., \& Filipovic, D.J. (2015), All your friends like this: How social networks took over news (pp. 5-26, 209-246). HarperCollins.

Darrow, C.S. (1893). Realism in literature and art. Arena, 9, 109.

Daston, L., \& Galison, P. (2010). Objectivity. Zone Books.

Deephouse, D.L., \& Carter, S.C. (2005). An examination of differences between organizational legitimacy and organizational reputation. Journal of Management Studies, 42(2), 329.

Duffy, J. (1968). A history of public health in New York city, 1625-1866 (pp. 225, 427, 431432, 436). Russell Sage Foundation. 
Duffy, J. (1990). The sanitarians: A history of American public health (pp. 126-137, 175-192, 221-238). University of Illinois Press.

Duncan, J.W., \& Shelton, W.C. (1978). Revolution in United States statistics, 1926-1976 (pp. 21-22). Office of Federal Statistical Policy and Standards.

Dupree, A.H. (1957). Science in the federal government: A history of policies and activities to 1940 (pp. 289-343). Harvard University Press.

Filler, L. (1976). The muckrakers: New and enlarged edition of crusaders for American liberalism. Pennsylvania State University.

Foucault, M. (1984). What is enlightenment? In P. Rabinow (Ed.), The Foucault reader. Pantheon Book.

Freed, R.N. (1967). Computer law searching: Problems for the layman. Datamation, 13(12), $38-43$

Freidson, E. (1986). Professional powers: A study of the institutionalization of formal knowledge. University of Chicago Press.

Freidson, E. (2001). Professionalism: The third logic. University of Chicago Press.

Friedman, W. (2013). Fortune tellers: The story of America's first economic forecasters. Princeton University Press.

Gabor, A. (1992). The man who discovered quality: How W. Edwards Deming brought the quality revolution to America. Penguin.

Galambos, L. (2012). The creative society: And the price Americans paid for it (pp. 35-37). Cambridge University Press.

Gallagher, A. (2006). The muckrakers: American journalism during the age of reform. Rosen Publishing Group.

García, R.V., \& Tardío, M.Á. (2017). 1936: Fraude y violencia en las elecciones del Frente Popular. Espasa.

Geiger, R.L. (1986). To advance knowledge: The growth of American research universities, 1900-1940. Oxford University Press.

Gordon, E.E., \& Gordon, E.H. (2003). Literacy in America: Historic journey and contemporary solutions (pp. 11-12, 20). Praeger.

Gordon, R.J. (2016). The rise and fall of American growth: The U.S. standard of living since the civil war (pp. 1-61). Princeton University Press.

Gower, B. (1997). Scientific method: A historical and philosophical introduction. Routledge.

Graves, L.C. (2016). Deciding what's true: The rise of political fact-checking in American journalism (pp. 7). Columbia University Press.

Great Smoky Mountains Trail Map and Guide. (2014). http://friendsofthesmokies.org/wpcontent/uploads/2018/04/Trail-Map-GSMNP-06-2014.pdf

Greenstein, S. (2015). How the Internet became commercial: innovation, privatization, and the birth of a new network (pp. 127). Princeton University Press.

Hacking, I. (1999). The Social Construction of What? Harvard University Press.

Hall, R. (1992). The strategic analysis of intangible resources. Strategic Management Journal $13(2), 135-144$.

Hearn, C.G. (2002). Tracks in the sea: Matthew Fontaine Maury and the mapping of the oceans (pp. 95-122, 159-218). International Marine/Ragged Mountain Press.

Hitlin, P. (2018). Internet, social media use and device ownership in U.S. have plateaued after years of growth. Pew Research Center Data, September 28. 
https://www.nature.com/articles/s41467-018-06930-

7?utm_source=newsletter\&utm_medium $=$ email\&utm_campaign=newsletter_axiosam\& stream $=$ top

https://www.varsitytutors.com/earlyamerica/jefferson-primer/agronomist

Jardine, L., \& Stewart, A. (2000). Hostage to fortune: The troubled life of Francis Bacon. Hill \& Wang.

Jewett, T. (n.d.). Jefferson: The agronomist. Varsity tutors.

Johnson, H.T., \& Kaplan, R.S. (1987). Relevance lost: The rise and fall of management accounting (pp. 47-60). Harvard Business School Press.

Kaestle, C.F. (2007). Seeing the sites, readers, publishers, and local print cultured in 1880. In C.F. Kaestle \& Radway (Eds.), A history of the book in America, vol. 4, Print in motion: The expansion of publishing and reading in the United States, 1880- 1940 (pp. 29). North Carolina Press.

Kett, J.E. (1994). The pursuit of knowledge under difficulties: From self-improvement to adult education in America, 1750-1990. Stanford University Press.

Kline, M. (1982). Mathematics: The loss of certainty. Galaxy Books.

Law, M.T., \& Libecap, G.D. (2006). The determinants of progressive era reform: The pure food and drug act of 1906. In E. L. Glaeser \& C. Goldin (Eds.). Corruption and reform: Lessons from America's economic history (pp. 319-342). University of Chicago Press for the National Bureau of Economic Research.

Lepore, J. (2018). These truths: A history of the United States (pp. 348-349). W.W. Norton \& Company.

Levenstein, M. (1998). Accounting for growth: Information systems and the creation of the large corporation. Stanford University Press.

Lewis, M. (2018). The fifth risk (pp. 152-219). Norton.

Linlater, A. (2002). Measuring America: How an untamed wilderness shaped the United States and fulfilled the promise of democracy. Walker Books.

Long, J.A. (2003). Computer aided legal research. Delmar Learning.

Marcus, A.I., Bix, A.S., Kay, G., Grim, V., \& Effland, A.B. (2015). Service as mandate: How American land-grant universities shaped the modern world, 1920-2015. The University of Alabama Press.

Marcus, A.I., Geiger, R.L., Finlay, M.R., Sorber, N.M., \& Rueber, M. (2015). Science as Service: Establishing and reformulating American land-grant universities, 1865-1930. The University of Alabama Press.

Markham, E. (1914). Children in bondage. Hearst's International Library Company.

Martin, H.J. (1994). The history and power of writing (pp. 137-139, 143-144). University of Chicago Press.

Maxfield, D.M. (1988). Online database search services directory. Gale.

Megill, A. (Ed.). (1994). Rethinking objectivity. Duke University Press

Meyer, J.W., \& Rowan, B. (1997). Institutionalized organizations: Formal structure as myth and ceremony. American Journal of Sociology, 83(2), 340-363.

Murray, J.E. (1997). Lawyers, computers, and power: Address, April 20, 1977.

National Assessment of Adult Literacy. (n.d.). Literacy from 1870 to 1979. National Center for Education Statistics.

National Center for Education Statistics (n.d.). Literacy from 1870 to 1979, National assessment of adult literacy. https://nces.ed.gov/naal/lit_history.asp\#enrollment

National Council of Teachers of Mathematics. (1970). History of mathematics education in the United States and Canada. National Council of Teachers. 
Nietzsche, F. (1873). On truth and lies in the nonmoral sense. $\mathrm{http} / / /$ nietzsche.holtof.com/Nietzsche_various/on_truth_and_lies.htm

Nietzsche, F. (1886). Beyond good and evil (English translation by Helen Zimmern, Digireads, 2019)

Orvell, M. (1989). The real thing: Imitation and authenticity in American culture, 1880-1940 (pp. 106-108). University of North Carolina Press.

Pfeffer, J., \& Salancik, G.R. (1978). The external control of organizations: A resource dependence perspective. Harper \& Row.

Pinker, S. (2018). Enlightenment now: The case for reason, science, humanism, and progress. Viking.

Poovey, M. (1998). A History of the modern fact. University of Chicago Press.

Previts, G.J., \& Merino, B.D. (1998). A history of accountancy in the United States: The cultural significance of accounting. University Press.

Rankin, J.L. (2018). A people's history of computing in the United States. Harvard University Press.

Reese, W.L. (2005). America's public schools: From the common school to no child left behind (pp. 10-148). Johns Hopkins University Press.

Reich, L.S. (1985). The making of American industrial research: Science and business at GE and Bell, 1876-1926 (pp. 1-12, and passim). Cambridge University Press.

Riss, J. (1892). The children of the poor. Scribner.

Roberts, D.L. (2012). American mathematicians as educaters (pp. 1893-1923). Docent Press.

Roosevelt, T. (1958). Autobiography: Condensed from the original edition, supplemented by letters, speeches, and other writings (edited by Wayne Andrews). Charles Scribner's Sons.

Schiller, D. (1981). Objectivity and the news: The public and the rise of commercial journalism. University of Pennsylvania Press.

Schwoch, J. (2018). Wired into nature: They telegraphed the North American frontier (pp. 139). University of Illinois Press.

Scranton, P., \& Fridenson, P. (2013). Reimagining business history (pp. 51-54). Johns Hopkins University Press.

Shao, C., Ciampaglia, G.L., Varol, O., Yang, KC. Flammini, A., \& Menczer, F. (2018). The spread of low-credibility content by social bots. Nature Communications, November 20.

Shapin, S., \& Schaffer, S. (1986). Leviathan and the air-pump: Hobbes, Boyle, and the experimental life. Princeton University Press.

Shrum, W., \& Withnow, R. (1988). Reputational status of organizations in technical systems. American Journal of Sociology, 93(2), 882-912.

Silverman, C. (2007). Regret the error: How media mistakes pollute the press and imperil free speech (pp. 39-48). Union Square.

Sinclair, U. (1906). The jungle. Serialized in The Sun newspaper.Sinclair, N. (2008). The history of geometry curriculum in the United States (pp. 13-70). Information Age Publishing.

Sismondo, S. (2009). An introduction to science and technology studies (2nd ed.). WileyBlackwell.

Slotten, H.R. (2000). Radio and television regulation: Broadcast technology in the United States, 1920-1960. Johns Hopkins University Press. 
Sobel, D. (1998). Longitude: The true story of a lone genius who solved the greatest scientific problem of his time. Walker \& Co.

Stevens Jr., E. (1995). The grammar of the machine: Technical literacy and early industrial expansion in the United States (pp.1-2). Yale University Press.

Stephens, L. (1904). The shame of the cities. S.S. McClure.

Stigler, S.M. (2002). Statistics on the table: The history of statistical concepts and methods. Harvard University Press.

Stigler, S.M. (1986). The History of statistics: The measurement of uncertainty before 1900. Belknap Press.

Stocking, G, (2018). Social media bots draw public's attention and concern. Pew Research Center, October 15, 2018.

Tarbell, I.M. (1904). The history of the standard oil company. Phillips and Co. (Reprinted, New York: Cosimo Classics, 2010).

Tuchman, B.W. (1966). The proud tower: A portrait of the world before the war, 1890-1914. Macmillan.

US Military, Headquarters Department of the Army. (2001). Map reading and land navigation, FM 3-25.26. U.S. Army.

Vital speeches. (1977, June 1). 43, 487-490.

Wagoner Jr, J.L. (2013). American education: A history (pp. 55-208). Routledge.

Weigelt, K., \& Camerer, C. (1998). Reputation and corporate strategy: A review of recent theory and applications. Strategic Management Journal, 9(5), 443-454.

Weinberger, D. (2011). Too big to know: Rethinking knowledge now that the facts aren't the facts, experts are everywhere, and the smartest person in the room is the room (pp. 141). Basic Books.

Wells, I.B. (2014). On lynchings. Dover Publications. (Unabridged republication of three books: Southern horrors, published by New York Age Print, 1892; A red record, published by Donohue \& Henneberry, 1895; Mob rule in New Orleans, published by Ida B. Wells, 1900)

Weyr, T. (1992). The wiring of Simon \& Schuster. Publishers Weekly, 239(25), 33.

White, H. (1973). Metahistory: The historical imagination in nineteenth-century Europe. Johns Hopkins University Press.

Wiebe, R. (1967). The search for order, 1877-1920. Hill \& Wang.

Wilson, H.S. (1970). McClure's magazine and the muckrakers. Princeton University Press.

Wood, J.P. (1949). Magazines in the United States: Their social and economic influence (pp. 250). Ronald Press.

Yost, J.R. (2017). Making IT work: A history of the computer services industry. MIT Press.

Young, J.H. (1961). The toadstool millionaires: A social history of patent medicines in America before federal regulation (pp.226-269). Princeton University Press.

Zimmern, H. (2009). Beyond good and evil. https://www.gutenberg.org/files/4363/4363h/4363-h.htm 